\title{
Sistem Informasi Pendukung Keputusan Terhadap Mutu Lulusan dengan Metode Fuzzy Model Tsukamoto
}

\author{
Ahmad Lubis Ghozali ${ }^{\mathrm{a},}{ }^{*}$, Mustafid $^{\mathrm{b}}$, Farikhin ${ }^{\mathrm{c}}$ \\ ${ }^{a}$ Politeknik Indramayu, Jawa Barat \\ burusan Statistika Fakultas Sains dan Matematika Universitas Diponegoro Semarang \\ 'Jurusan Matematika Fakultas Sains dan MatematikaUniversitas Diponegoro Semarang
}

Naskah Diterima : 11 April 2014; Diterima Publikasi : 20 Mei 2014

\begin{abstract}
The importance of graduate information systems to support leadership in taking a decision related to the development of alumni, so that should make for a graduate information systems implemented in the form of web portals. Analysis of the data processed by the method of OLAP (Online Analytical Processing), KPI (Key Performance Indicators) graduates, and data mining to extract and transform data holds the data will be stored in the warehouse. The process of data analysis using OLAP and Fuzzy method to determine the parameters of the model Tsukamoto graduate performance and quality of college graduates. The process of data analysis is represented in the form of tables, graphs, and dashboards, then used as a prop for academic results. OLAP analysis result data processed using the fuzzification, inference, and defuzzification to produce quality graduates index. These findings form a web-based information systems graduate portal with content features alumni and stakeholders as a graduate performance indicators that can be accessed through an Internet connection. The information system produces graduates index KPI performance and quality of graduates graduated as a decision support by the leadership and the head of the research program carried out at the University, KPI graduates to indicate that the parameters of the specific level of quality graduates and overall views of the dimensions of the year and course of study, such as in 2011 the level of quality of graduates of IT course overall "Good", TM course as a whole "Good", TP courses overall "Good".
\end{abstract}

Keywords: Information systems graduates; OLAP, KPI graduates; Tsukamoto Fuzzy Logic model

\begin{abstract}
Abstrak
Sistem informasi lulusan dalam bentuk web portal untuk mendukung dalam mengambil keputusan yang berkaitan dengan perkembangan alumni, tujuan analisis data menggunakan metode OLAP dan metode Fuzzy model Tsukamoto untuk menentukan parameter performa lulusan dan mutu lulusan perguruan tinggi. Proses analisis data tersebut direpresentasikan berdasarkan dimensi tahun dan program studi dalam bentuk tabel, grafik, dan dashboard, sehingga menghasilkan output yang dapat digunakan sebagai pendukung keputusan akademik. Data hasil analisis OLAP diolah menggunakan proses fuzzifikasi, inferensi, dan defuzzifikasi untuk menghasilkan indeks mutu lulusan. Hasil penelitian ini berupa sistem informasi lulusan berbasis web portal yang menghasilkan indeks KPI performa lulusan dan mutu lulusan sebagai pendukung keputusan oleh pihak manajemen institusi Perguruan Tinggi yang dapat digunakan sebagai bahan evaluasi, sehingga kebutuhan untuk meningkatkan parameter keberhasilan mutu lulusan secara keseluruhan dapat dilakukan dengan lebih baik.
\end{abstract}

Kata kunci: Sistem Informasi Lulusan; OLAP; KPI Lulusan; Logika Fuzzy Model Tsukamoto

\section{Pendahuluan}

Informasi perkembangan lulusan suatu hal yang penting bagi Perguruan Tinggi untuk mengetahui seberapa baik mutu lulusannya, oleh sebab itu barometer lulusan menjadi suatu nilai bisnis yang memberikan pengaruh besar terhadap peningkatan kepercayaan masyarakat kepada institusi pendidikan dalam menentukan baik atau buruknya lulusan dari Perguruan Tinggi (Patria, 2013).

Kegiatan dalam suatu sistem informasi menghasilkan sebuah informasi yang dibutuhkan bagi organisasi untuk membuat keputusan,

*) Penulis korespondensi: alghoz@gmail.com pengendalian operasi, menganalisis masalah, dan menciptakan produk baru atau jasa. Kegiatan dalam sistem informasi tersebut merupakan input, proses, dan output (Laudon et al., 2010). Evaluasi performance siswa menggunakan fuzzy logic yang dimana pada penelitiannya menggunakan parameter quisioner dalam lima pertanyaan dari 10 sampel siswa, untuk mengetahui seberapa besar tes atau ujian mempengaruhi kualitas performance siswa. Pendekatan metodenya yaitu Fuzzy Logic Controller (FLC) dengan menggunakan two-node evaluation dapat memberikan nilai motivasi dan semangat yang baik kepada siswa (Ingoley dan Bakal, 2012). 
Online Analytical Processing (OLAP) bagian dari solusi umum bagi perusahaan-perusahaan modern untuk menghasilkan, memantau, berbagi, dan analisis administrasi laporan mereka. Hasil laporan dapat ditampilkan secara harian, mingguan, danatau bulanan yang menggunakan analisis OLAP, semua analisis tentang isi laporan yang tersisa untuk pembaca laporan menemukan aturan tersembunyi, laporan serupa, atau trend dalam jumlah yang berpotensi laporan besar (Hsu dan Li, 2011).

Business Intelligence (BI) bagian dari konsep manajerial yang mengacu pada seperangkat program dan teknologi yang memberikan kemampuan mengumpulkan, menganalisis dan mengakses data proses organisasi. BI membantu organisasi yang memiliki pengetahuan komprehensif tentang faktorfaktor yang mempengaruhi organisasi. Tujuan utama dari sistem BI dalam organisasi apapun adalah untuk membantu membuat keputusan yang optimal dan cepat dalam organisasi (Rouhani et al., 2012).

Pentingnya informasi untuk mengetahui perkembangan lulusan, yang dilihat dari sudut pandang informasi eksekutif dan strategis serta aspek lainnya pada periode tertentu, sehingga hal tersebut mendasari penelitian ini. Adapun perbedaan yang dilakukan penelitian ini dengan penelitian terdahulu adalah terletak pada pendukung keputusan terhadap mutu lulusan yang menggunakan konsep ETL dan dianalisis menggunakan OLAP untuk menentukan indeks KPI, kemudian indeks KPI tersebut dianalisis menggunakan metode Logika Fuzzy Model Tsukamoto untuk mengevaluasi lulusan. Selain itu, menghasilkan perangkat lunak berupa web portal Sistem Informasi Lulusan yang dapat dilakukan secara online, kemudian output dari penelitian ini berupa tabel, grafik, dan dashboard performa dan mutu lulusan perguruan tinggi.

\section{Kerangka Teori}

\subsection{Online Analytical Processing (OLAP)}

Kebutuhan untuk analisis data multidimensi sebagai dukungan untuk pengambilan keputusan bisnis yang telah hadir selama beberapa dekade terakhir ini. Teknologi Online Transaction Processing (OLTP) diterima dengan baik pada pasar pengguna sistem informasi akan tetapi tidak dirancang untuk tugas-tugas dalam menangani BI dan oleh karena itu, teknologi OLAP dikembangkan sebagai solusinya. Pengguna teknologi OLAP telah menggantikan teknologi dari OLTP adalah dapat mengimplementasikan berupa pelaporan analisis kubus (Cube Reporting Analysis) pada data yang diambil secara langsung dalam relasional sebuah perangkat basis data tanpa memodifikasinya terlebih dahulu (Westerlund, 2008).

Model multidimensional sebuah proses dari pemodelan data didalam sebuah semesta dimana wacana penggunaan konstruksi konsep model disediakan oleh model data multidimensional. OLAP merupakan komponen penting dalam BI, dan OLAP juga disebut sebagai aplikasi Analytical dengan mempunyai kemampuan yang menyerupai Spreadsheet. OLAP dibangun berdasarkan multidimensional data model (Pedersen, 2009).

OLAP memberikan sudut pandang yang berbeda dari data untuk melakukan operasi yang berbeda terhadap data (Jadac dan Panchal, 2012).

\section{1) Operasi-Operasi OLAP}

OLAP terdapat beberapa operasi-operasi, yaitu;(a) Slicing dan Dicing:Operasi untuk melihat data sebagai visualisasi dari bentuk kubus. (b) Roll up dan Drill down: Operasi untuk melihat data global atau detail disepanjang level hirarki dimensi (Golfarelli et al., 2012).

\section{2) Kubus (Cubes)}

Cubes merupakan sebuah bentuk database dimana data disimpan dalam bentuk Cell, dan posisi dari sel-sel tersebut ditentukan oleh beberapa variabel yang disebut dengan Dimension. Jumlah Dimension ini secara teori bisa tidak terbatas, tidak perlu terkuantifikasi untuk membentuk sebuah bangun 3 dimensi berupa cube. Istilah Cube dan penggambaran dalam bentuk cube (3 dimensi) ini dimaksud untuk mempermudah visualisasi kita tentang sifat multi dimensionalnya (Kimball dan Caserta, 2004).

\section{3) Alur Pembuatan Cube}

Alur pembuatan cube terdiri dari beberapa langkah yaitu menentukan nama cube, memilih tabel fakta, memilih measure, dan kemudian memilih dimension (Golfarelli et al., 2012). Pada Gambar 2.1 di bawah ini menunjukkan bentuk cube dan dimensi.

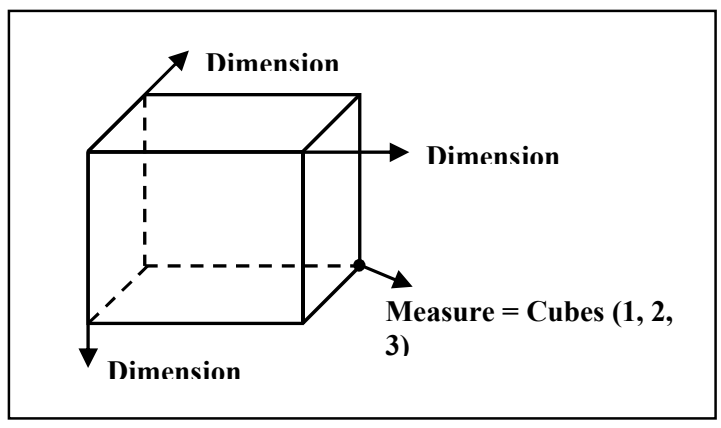

Gambar 1. Cube dan dimensi (Golfarelli et al., 2012)

Pada Gambar 1 di atas menerangkan sebuah tabel fakta yang menyimpan measure dan tabel dimensi yang menyimpan atribut sumbu cube atau dimensi, seperti dimensi 1, dimensi 2, dimensi 3 dan seterusnya. Cube dengan N-Dimensi mengandung sebuah set dari nilai unik yang mengidentifikasi dan mengkategorikan data. 


\subsection{Logika Fuzzy}

Logika Fuzzy salah satu komponen pembentuk soft computing. Logika Fuzzy pertama kali diperkenalkan oleh Prof. Lotfi A. Zadeh pada tahun 1965. Logika fuzzy adalah metode yang mempunyai kemampuan untuk memproses variabel yang bersifat kabur atau tidak dapat dideskripsikan secara eksak/pasti seperti halnya tinggi, lambat, bising, dan lain-lain. Dalam variabel logika fuzzy yang bersifat kabur tersebut dapat direpresentasikan sebagai himpunan yang anggotanya merupakan suatu nilai crisp dan derajat keanggotaannya (membership function) dalam himpunan tersebut.

Pada teori himpunan fuzzy, peranan derajat keanggotaan sebagai penentu keberadaan elemen dalam suatu himpunan sangatlah penting. Nilai keanggotaan atau derajat keanggotaan (membership function) menjadi ciri utama dari penalaran dengan logika fuzzy tersebut (Kusumadewi, 2010).

\section{1) Himpunan Fuzzy (Fuzzy Sets)}

Pada himpunan fuzzy nilai keanggotaannya terletak pada rentang 0 sampai 1 . Apabila $x$ memiliki nilai keanggotaan fuzzy $\mu \mathrm{A}(\mathrm{x})=0$ berarti $\mathrm{x}$ tidak menjadi anggota himpunan $\mathrm{A}$, demikian pula apabila $\mathrm{x}$ memiliki nilai keanggotaan fuzzy $\mu \mathrm{A}(\mathrm{x})=1$ berarti $\mathrm{x}$ menjadi anggota penuh pada himpunan $\mathrm{A}$, sedangkan pada himpunan crisp, nilai keanggotaan hanya ada 2 (dua) kemungkinan, yaitu nol dan satu.

\section{2) Fungsi Keanggotaan (Membership Function)}

Fungsi keanggotaan merupakan suatu kurva yang menunjukkan pemetaan titik-titik input data ke dalam nilai keanggotaannya atau sering juga disebut dengan derajat keanggotaan yang memiliki interval Antara 0 sampai 1. Salah satu cara yang dapat digunakan untuk mendapatkan nilai keanggotaan adalah dengan melalui pendekatan fungsi, ada beberapa fungsi yang dapat digunakan, yaitu Representasi Kurva Segitiga (Kusumadewi, 2010).

Kurva segitiga pada dasarnya merupakan gabungan Antara 2 garis (linier), persamaan fungsi keanggotaannya ditunjukkan pada Gambar 2.

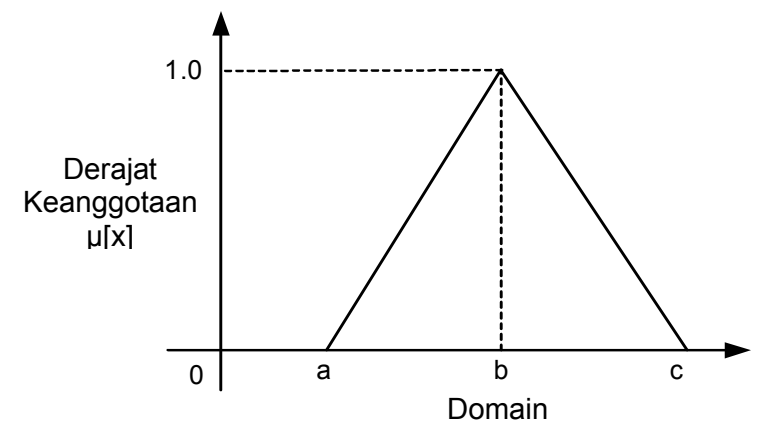

Gambar 2. Representasi kurva segitiga (Yadav dan Singh, 2011)
Fungsi keanggotaannya $\mu[\mathrm{x}]$ Kurva Segitiga:

$\begin{aligned} \mu[\mathrm{x}] & = \begin{cases}0 ; & \mathrm{x} \leq \mathrm{a} \text { atau } \mathrm{x} \geq \mathrm{c} \\ (\mathrm{x}-\mathrm{a}) /(\mathrm{b}-\mathrm{a}) ; & \mathrm{a}<\mathrm{x} \leq \mathrm{b} \\ (2.1) & \end{cases} \\ (\mathrm{b}-\mathrm{x}) /(\mathrm{c}-\mathrm{b}) ; & \mathrm{b}<\mathrm{x} \leq \mathrm{c}\end{aligned}$

Keterangan:

$\mu[\mathrm{x}]$ : Himpunan Fuzzy

$\mathrm{x} \quad$ : Data Crisp

a : Nilai Domain batas bawah

b : Nilai Domain tengah

c : Nilai Domain batas atas

3) Operator Dasar untuk Operasi Himpunan Fuzzy

Beberapa operasi yang diartikan secara khusus untuk mengkombinasi dan memodifikasi himpunan fuzzy, nilai keanggotaan merupakan sebuah hasil dari operasi himpunan biasanya disebut dengan nama fire strength atau $\alpha$-predikat, operator dasar yang diciptakan oleh Zadeh, yaituOperasi AND (Intersection A $\cap \mathrm{B})(\mathrm{Cox}, 1994)$.

Operator AND berhubungan dengan operasi interseksi pada himpunan, $\alpha$-predikat sebagai hasil operasi dengan operator AND diperoleh dengan mengambil nilai keanggotaan terkecil antar elemen pada himpunan-himpunan yang bersangkutan.

$\mu_{(\mathrm{A} \cap \mathrm{B})}=\min \left(\mu_{\mathrm{A}}(\mathrm{x}), \mu_{\mathrm{B}}(\mathrm{y})\right)$

(2.2)

Keterangan :

- $\mu_{(\mathrm{A} \cap \mathrm{B})}$ adalah fire strength atau $\alpha$-predikat untuk himpunan $\mathrm{A}$ dan $\mathrm{B}$.

- $\min \left(\mu_{\mathrm{A}}(\mathrm{x}), \mu_{\mathrm{B}} \quad(\mathrm{y})\right)$ adalah nilai keanggotaan terkecil antar elemen pada himpunan A dan B.

- (x),(y) adalah nilai keanggotaan.

4) Penalaran Monoton

Metode penalaran secara monoton digunakan sebagai dasar untuk teknik implikasi fuzzy, meskipun penalaran ini sudah jarang sekali digunakan, namun terkadang masih digunakan untuk penskalaan fuzzy. Jika 2 (dua) daerah fuzzy direlasikan dengan implikasi sederhana sebagai berikut (Cox, 1994) :

IF $x$ is $A$ THEN $y$ is $B$

Keterangan :

- $x$ dan $y$ adalah variabel fuzzy.

- $A$ dan $B$ adalah himpunan fuzzy.

- $x$ is $A$ adalah anteseden atau proposisi yang mengikuti IF.

- $y$ is $B$ adalah konsekuen atau proposisi yang mengikuti THEN.

\section{5) Fungsi Implikasi}

Tiap-tiap aturan (proposisi) pada basis pengetahuan fuzzy akan berhubungan dengan suatu relasi fuzzy. Bentuk umum dari aturan yang digunakan dalam fungsi implikasi pada persamaan 
2.6, proposisi ini dapat diperluas dengan menggunakan operator fuzzy, seperti (Cox, 1994) :

$\operatorname{IF}\left(\mathrm{x}_{1}\right.$ is $\left.A_{1}\right) o\left(x_{2}\right.$ is $\left.A_{2}\right)$ o...o $\left(x_{n}\right.$ is $\left.A_{n}\right)$ THEN $y$ is $B$

Keterangan :

- o adalah operator OR atau AND.

- $\mathrm{x}_{\mathrm{n}}$ atau $\mathrm{x}_{1}, \mathrm{x}_{2}, .$. dst. adalah variabel fuzzy.

- $\mathrm{A}_{\mathrm{n}}$ atau $\mathrm{A}_{1}, \mathrm{~A}_{2}$,..dst. adalah himpunan fuzzy ke-i sebagai anteseden.

- y adalah variabel fuzzyoutput.

- B adalah himpunan fuzzyoutput dari y.

\subsection{Fuzzy Inference System (FIS)}

Fuzzy Intference System atau Fuzzy Expert System merupakan seperangkat program yang memanipulasi encoded knowledge (pengetahuan yang disandikan) untuk memecahkan masalah dalam sebuah kasus domain dan biasanya membutuhkan keahlian seorang manusia. FIS juga diperoleh dari berbagai sumber para ahli atau pakar dan kemudian dikodekan dalam bentuk yang cocok untuk sebuah sistem yang selanjutnya digunakan dalam inferensi atau keputusan dan proses penalaran (Yadav dan Singh, 2011).

Knowledge atau pengetahuan para ahli (pakar) harus diperloleh dari sumber ahli berupa teks, artikel jurnal dan basis data. Jenis pengetahuan ini biasanya membutuhkan banyak pelatihan dan pengalaman dibeberapa bidang khususnya seperti kedokteran, konfigurasi sistem, dan desain rekayasa. Struktur dasar Fuzzy Inference System diberikan pada Gambar 3. (Ingloey dan Bakal, 2012).

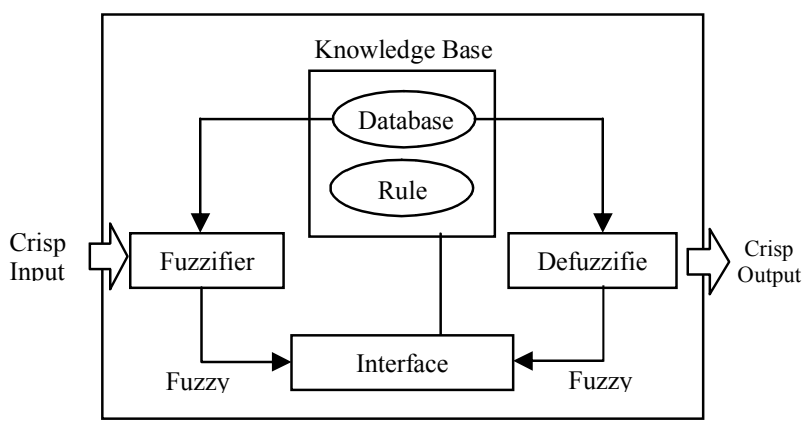

Gambar 3. Struktur dasar FIS (Ingloey dan Bakal, 2012)

\subsection{Fuzzy Model Tsukamoto}

Inferensi model Tsukamoto merupakan proses penggabungan banyak aturan berdasarkan data yang tersedia. Komponen yang melakukan inferensi dalam sistem pakar disebut mesin inferensi. Dua pendekatan untuk menarik kesimpulan pada IF-THEN rule (aturan jika-maka) adalah forward chaining dan backward chaining (Turban et al., 2005).

\section{1) Forward Chaining}

Forward chaining mencari bagian JIKA terlebih dahulu. Setelah semua kondisi dipenuhi, aturan dipilih untuk mendapatkan kesimpulan. Jika kesimpulan yang diambil dari keadaan pertama, bukan dari keadaan yang terakhir, maka ia akan digunakan sebagai fakta untuk disesuaikan dengan kondisi JIKA aturan yang lain untuk mendapatkan kesimpulan yang lebih baik. Proses ini berlanjut hingga dicapai kesimpulan akhir.

\section{2) Backward Chaining}

Backwardchaining kebalikan dari forward chaining, pendekatan ini dimulai dari kesimpulan dan hipotesis bahwa kesimpulan adalah benar. Mesin inferensi kemudian mengidentifikasi kondisi JIKA yang diperlukan untuk membuat kesimpulan benar dan mencari fakta untuk menguji apakah kondisi JIKA adalah benar, apabila semua kondisi JIKA adalah benar, maka aturan dipilih dan kesimpulan dicapai. Apabila beberapa kondisi salah, maka aturan dibuang dan aturan berikutnya digunakan sebagai hipotesis kedua. Apabila tidak ada fakta yang membuktikan bahwa semua kondisi JIKA adalah benar atau salah, maka mesin inferensi terus mencari aturan yang kesimpulannya sesuai dengan kondisi JIKA yang tidak diputuskan untuk bergerak satu langkah ke depan memeriksa kondisi tersebut. Proses ini berlanjut hingga suatu set aturan didapat untuk mencapai kesimpulan atau untuk membuktikan tidak dapat mencapai kesimpulan.

Metode defuzifikasi yang digunakan dalam model Tsukamoto adalah metode defuzifikasi rata-rata terpusat (Center Average Defuzzyfier) yang dirumuskan pada persamaan 2.5(Kusumadewi, 2010).

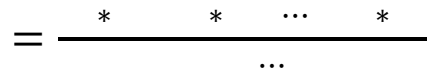

Keterangan :

Z : Nilai rata-rata terpusat.

: Nilai $\alpha$-predikat (fire strength) yang dimana nilainya tidak sama dengan nol.

: Nilai output yang berupa konstanta dari nilai keanggotaan yang berhubungan dengan anteseden.

\section{Metodologi}

\subsection{Prosedur Penelitian}

Prosedur penelitian dimulai dengan mengidentifikasi masalah, kemudian pemilihan data, pengolahan data dengan proses ekstraksi, transformasi dan loading (ETL), perancangan dan implementasi data warehouse. Tahapan berikutnya merupakan pengolahan data dan analisis menggunakan OLAP dan metode Fuzzy model Tsukamoto, perancangan sistem informasi berbasis web portal, dan pengujian sistem.

Pengambilan data selain dari hasil wawancara juga data di ambil langsung dari pengguna sistem 
yaitu alumni dan stakeholder yang dapat menunjang keakuratan data penelitian, sehingga data tersebut akan masuk ke dalam beberapa variabel yang diantaranya variabel sertifikasi kompetensi, kesesuaian bidang ilmu, dan kesesuaian stakeholder terhadap alumni.

Pengambilan data dari pengguna admin digunakan untuk mendapatkan dan mengumpulkan informasi secara online baik dari database Sistem Informasi Akademik, Sistem Informasi Lulusan yang telah diinputkan dari pihak alumni maupun pihak stakeholder yang berkaitan dengan masalah dalam penelitian.

\subsection{Pengolahan Data Analisis Metode Fuzzy Tsukamoto}

Hasil yang diperoleh dari analisis OLAP berupa Matrik objek atau Key Performance Indicators (KPI) berupa rata-rata lulusan berdasarkan rata-rata IPK, rata-rata waktu tunggu, rata-rata sertifikasi kompetensi, rata-rata kesesuaian bidang ilmu, dan rata-rata kesesuaian stakeholder terhadap lulusan, indikator ini berdasarkan pada standar BAN-PT, KKNI dan kebijakan yang berlaku di Politeknik Indramayu, kemudian indikator tersebut di-fuzzy-kan untuk menghasilkan sebuah pendukung keputusan. Prosedur analisis metode Fuzzy Model Tsukamoto sebagai berikut:

1) Menentukan variabel fuzzy

Variabel fuzzydari beberapa indikator yang mengacu pada standar BAN-PT, KKNI dan kebijakan yang berlaku di Politeknik Indramayu, indikator tersebut seperti pada Tabel 1.

Tabel 1. Data Standar KPI Lulusan

\begin{tabular}{|c|c|c|c|c|c|}
\hline \multirow[b]{2}{*}{ No } & \multirow{2}{*}{$\begin{array}{l}\text { Variabel } \\
\text { Performa } \\
\text { KPI Lulusan }\end{array}$} & \multirow{2}{*}{$\begin{array}{l}\text { Himpunan } \\
\text { Fuzzy }\end{array}$} & \multicolumn{3}{|c|}{ Range } \\
\hline & & & a & $\mathrm{b}$ & $\mathrm{c}$ \\
\hline \multirow[t]{2}{*}{1} & 2 & 3 & 4 & 5 & 6 \\
\hline & & Cukup & & 2.50 & 3.00 \\
\hline \multirow[t]{3}{*}{1} & IPK & Baik & 2.75 & 3.25 & 3.75 \\
\hline & & Sangat Baik & 3.50 & 3.90 & \\
\hline & & Baik & & 6 & 10 \\
\hline \multirow[t]{2}{*}{2} & waktu r unggu & Cukup & 8 & 12 & 16 \\
\hline & & Kurang & 14 & 18 & \\
\hline \multirow{3}{*}{3} & Sertifikasi & Kurang & & 25 & 45 \\
\hline & Komnetensi & Cukup & 35 & 55 & 75 \\
\hline & Kompetens1 & Baik & 65 & 85 & \\
\hline \multirow{3}{*}{4} & Kesesuaian & $\begin{array}{l}\text { Kurang } \\
\text { Sesuai }\end{array}$ & & 25 & 45 \\
\hline & Bidang Ilmu & Sesuai & 35 & 55 & 75 \\
\hline & $(\%)$ & Sangat Sesuai & 65 & 85 & \\
\hline \multirow{3}{*}{5} & $\begin{array}{l}\text { Kesesuaian } \\
\text { Stakeholder }\end{array}$ & $\begin{array}{l}\text { Kurang } \\
\text { Sesuai }\end{array}$ & & 25 & 45 \\
\hline & terhadap lulusan & Sesuai & 35 & 55 & 75 \\
\hline & $(\%)$ & Sangat Sesuai & 65 & 85 & \\
\hline
\end{tabular}

Keterangan:

Kolom 2 : Variabel yang akan dibahas dalam suatu sistem fuzzy
Kolom 3 : Suatu grup yang akan mewakili suatu kondisi atau keadaan tertentu dalam suatu variabel fuzzy

Kolom 4 : Batas nilai bawah domain himpunan fuzzy

Kolom 5 : Titik tengah nilai domain himpunan fuzzy

Kolom 6 : Batas nilai atas domain himpunan fuzzy

2) Membuat Fungsi keanggotaan (membership function)

Fungsi keanggotaan kurva yang menunjukkan pemetaan titik-titik input data ke dalam nilai keanggotaannya yang memiliki interval antara 0 sampai 1. Dalam penelitian ini melalui pendekataan fungsi yang dipakai adalah Representasi Kurva Segitiga dan Kurva Bahu. Persamaan fungsi keanggotaannya merujuk pada persamaan kurva bahu kiri, kurva segitiga, dan kurva bahu kanan, berikut ini Gambar 4. merupakan representasi kurva untuk variabel performa KPI lulusan IPK.

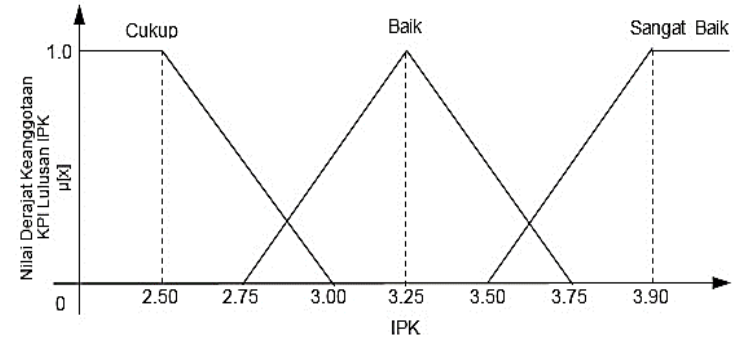

Gambar 4. Representasi kurva untuk KPI lulusan IPK

Gambar 4 menunjukkan representasi kurva untuk variabel performa KPI lulusan IPK, kemudian di implementasikan pada fungsi keanggotaan berdasarkan persamaan kurva bahu kiri adalah sebagai berikut :

$\mu_{\text {cukup }}[x]= \begin{cases}1 ; & x \leq 2.50 \\ (3.00-x) / 0.50 ; & 2.50<x \leq 3.00 \\ 0 ; & x>3.00\end{cases}$

Persamaan kurva segitiga adalah sebagai berikut:

$\mu_{\text {baik }}[x]= \begin{cases}0 ; & x \leq 2.75 \text { atau } x \geq 3.75 \\ (x-2.75) / 0.50 ; & 2.75<x \leq 3.25 \\ (3.75-x) / 0.50 ; & 3.25<x \leq 3.75\end{cases}$

Persamaan kurva bahu kanan adalah sebagai berikut:

$\mu_{\text {sangatbaik }}[x]= \begin{cases}0 ; & x \leq 3.50 \\ (x-3.50) / 0.40 ; & 3.50<x \leq 3.90 \\ 1 ; & x>3.90\end{cases}$ 
3) Proses Fuzzy Inference System (FIS)

Proses selanjutnya melakukan FIS, pada proses FIS ini terdapat 3 (tiga) tahapan, yaitu :

\section{a) Fuzzifikasi}

Mengambil nilai inputcrisp kemudian membandingkan dengan fungsi keanggotaan berdasarkan representasi kurva dan persamaan fungsi keanggotaan. Dalam hal ini menggunakan salah satu variabel performa KPI lulusan yaitu IPK, pada nilai rata-rata performa KPI lulusan IPK semua angkatan (3 tahun) dan semua program studi yaitu 2.97 dari hasil proses analisis OLAP. Kemudian nilai tersebut dibuat ke dalam nilai derajat keanggotaan yang sudah disesuaikan dengan standar KPI lulusan pada Tabel 1 berdasarkan pada pembentukan fungsi keanggotaan untuk variabel performa KPI lulusan IPK, yaitu :

Input $:$ IPK $=2.97$

Dicari derajat keanggotaan nilai variabel IPK dalam setiap himpunan dengan menggunakan persamaan 3.1 untuk bahu kiri.

$\mu_{\text {cukup }}[\mathbf{2 . 9 7}]= \begin{cases}1 ; & \boldsymbol{x} \leq 2.50 \\ (3.00-\boldsymbol{x}) / 0.50 ; & 2.50<\boldsymbol{x} \leq 3.00 \\ 0 ; & \boldsymbol{x}>3.00\end{cases}$

Pada himpunan cukup dengan $\mu_{\text {cukup }}$ [2.97], karena nilai $\boldsymbol{x}=2.97$ pada persamaan di atas, maka masuk ke fungsi atau persamaan $2.50<\boldsymbol{x} \leq 3.00$, untuk mencari nilai keanggotaannya yaitu :

$\mu_{\text {cukup }}[\mathbf{2 . 9 7}]=(3.00-2.97) / 0.50$

Nilai Performa KPI lulusan dari IPK 2.97 dengan persamaan 3.2 untuk kurva segitiga.

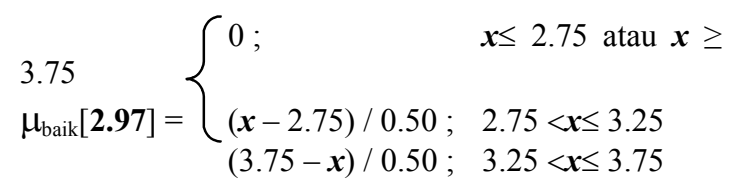

Pada himpunan baik dengan $\mu_{\text {baik }}[2.97]$, karena nilai $\boldsymbol{x}=2.97$ pada persamaan di atas, maka masuk ke fungsi atau persamaan $2.75<\boldsymbol{x} \leq 3.25$, untuk mencari nilai keanggotaannya yaitu :

$\begin{aligned} \mu_{\text {baik }}[\mathbf{2 . 9 7}] & =(2.97-2.75) / 0.50 \\ & =0.44\end{aligned}$

Nilai Performa KPI lulusan dari IPK 2.97 dengan persamaan 3.3 untuk bahu kanan.

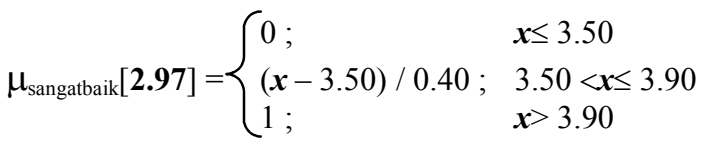

Pada himpunan sangatbaik dengan $\mu_{\text {sangatbaik }}$ [2.97], karena nilai $\boldsymbol{x}=2.97$ pada persamaan di atas, maka masuk ke fungsi atau persamaan $\boldsymbol{x} \leq$ 3.50 , untuk mencari nilai keanggotaannya yaitu

$\mu_{\text {sangatbaik }}[2.97]=0$

Hasil dari proses fuzzifikasi dengan nilai input 2.97 dari variabel performa KPI lulusan untuk IPK dengan membandingkan fungsi keanggotaannya, maka menghasilkan input fuzzy dari variabel performa KPI lulusan untuk IPK adalah sebagai berikut :

$\mu_{\text {cukup }}[\mathbf{2 . 9 7}]=0.06$
$\mu_{\text {baik }}[\mathbf{2 . 9 7}]=0.44$

$\mu_{\text {sangatbaik }}[2.97]=0$

Sehingga dari proses fuzzifikasi di atas menghasilkan performa KPI lulusan untuk IPK semua angkatan (3 tahun) dan semua program studi dengan nilai 2.97, input fuzzy yang mendekati angka 1 (satu) yaitu 0.44 dengan performa lulusan dari indikator IPK adalah "BAIK".

b) Inferensi

Nilai input fuzzy dimasukkan ke dalam aturan fuzzy dan yang memenuhi fungsi MIN dalam mencari fire strength, yaitu :

[R72] IF ipk cukup AND waktu tunggu baik AND sertifikasi kompetensi cukup AND bidang ilmu sangat sesuai AND stakeholder sangat sesuai THEN performa lulusan $=0.79$

$\alpha$-predikat $_{72}=\min (0.06 ; 1.00 ; 0.94 ; 0.84$; $0.72)$

$$
=0.06
$$

Performa lulusan $_{72}=0.79$

[R153]IF ipk baik AND waktu tunggu baik AND sertifikasi kompetensi cukup AND bidang ilmu sangat sesuai AND stakeholder sangat sesuai THEN performa lulusan $=0.83$

$\alpha$-predikat ${ }_{153}=\min (0.44 ; 1.00 ; 0.94 ; 0.84$; 0.72 )

$$
=0.44
$$

Performa lulusan $_{153}=0.83$

c) Defuzzifikasi

Pada Proses defuzzifikasi ini merupakan proses konversi dari setiap hasil yang dilakukan pada inferensi kemudian diekspresikan dalam bentuk fuzzyset ke satu bilangan real. Dalam implementasi logika fuzzy ini yang digunakan adalah metode weight average (rata-rata terbobot), sehingga dalam pengambilan nilai rata-rata dengan menggunakan pembobotan berupa derajat keanggotaan. Berikut ini cara perhitungan dalam proses defuzzifikasi berdasarkan hasil inferensi untuk mengetahui parameter tingkat mutu lulusan secara keseluruhan berdasarkan persamaan 2.9 : 


$$
\begin{aligned}
& =\frac{0.06 * 0.79+0.44 * 0.83}{0.06+0.44} \\
& =\frac{0.0474+0.3652}{0.5} \\
& =\stackrel{.}{-}=0.83
\end{aligned}
$$

Hasil dari analisis metode logika fuzzy model Tsukamoto parameter tingkat Mutu Lulusan menghasilkan nilai rata-rata keseluruhan 0.83, berdasarkan point Mutu Lulusan dengan menggunakan metode Chiew dan Salim, 2003 adalah "SANGAT BAIK".

Tabel 2. RangeParameter Tingkat Mutu Lulusan (Chiew dan Salim, 2003)

\begin{tabular}{clc}
\hline No & Mutu Lulusan & Range \\
\hline 1 & Sangat Tidak Baik & $0.0 \leq \mathrm{Z} \leq 0.2$ \\
2 & Kurang Baik & $0.2<\mathrm{Z} \leq 0.4$ \\
3 & Cukup & $0.4<\mathrm{Z} \leq 0.6$ \\
4 & Baik & $0.6<\mathrm{Z} \leq 0.8$ \\
5 & Sangat Baik & $0.8<\mathrm{Z} \leq 1.0$ \\
\hline
\end{tabular}

\section{Hasil dan Pembahasan}

\subsection{Hasil OLAP}

Penelitian ini mendapatkan sebuah hasil berupa Sistem Informasi Lulusan Perguruan Tinggi berbasis web portal yang dapat diakses melalui Internet, untuk input data-datanya berupa data lulusan mencakup data IPK, waktu tunggu mendapatkan pekerjaan, sertifikasi kompetensi, kesesuaian bidang ilmu, dan kesesuaian stakeholders terhadap lulusan yang proses inputnya dari beberapa Pengguna yaitu, Administrator, Alumni, dan Industri.

Data Lulusan dianalisis menggunakan OLAP dan Metode Fuzzy model Tsukamoto, hasil pengolahan dan analisis data sebagai parameter pendukung keputusan berupa indeks performa KPI Lulusan dan tingkat Mutu Lulusan pada Perguruan Tinggi yang disajikan dalam bentuk tabel, grafik, dan dashboard.

Dalam penelitian ini terdapat beberapa proses pembahasan yaitu menghasilkan dari analisis OLAP, menghasilkan dari analisis metode fuzzy model Tsukamoto, menghasilkan dari analisis indeks KPI lulusan, dan menghasilkan dari analisis tingkat mutu lulusan, sehingga untuk pembahasan lebih detailnya terdapat di bawah ini.

\subsection{Analisis OLAP}

Data dianalisis dengan metode OLAP, pada analisis OLAP data ditampilkan dalam bentuk tabel, grafik, dan dashboard berdasarkan dimensi tahun dan program studi, kemudian hasilnya berupa indeks KPI lulusan, dalam hal ini sampling datanya berupa IPK yaitu : a. Berdasarkan Dimensi Tahun dan Program Studi Indeks KPI berupa IPK terdapat rata-rata IPK pada tahun 2011 adalah Prodi TI 2.92, Prodi TM 2.98, dan Prodi TP 2.78. Tahun 2012 adalah Prodi TI 3.24, Prodi TM 3.02, dan Prodi TP 2.88. Tahun 2013 adalah Prodi TI 3.04, Prodi TM 2.91, dan Prodi TP 2.75.

b. Berdasarkan Dimensi Tahun dan Semua Program Studi

Indeks KPI berupa IPK terdapat rata-rata IPK pada tahun 2011 adalah 2.91, tahun 2012 adalah 3.05, dan tahun 2013 adalah 2.93.

c. Berdasarkan Dimensi Semua Angkatan (3 tahun) dan Program Studi

Indeks KPI berupa IPK terdapat rata-rata IPK pada Prodi TI adalah 3.08, Prodi TM adalah 2.97, dan Prodi TP adalah 2.82.

d. Berdasarkan Dimensi Semua Angkatan (3 tahun) dan Semua Program Studi

Indeks KPI berupa IPK terdapat rata-rata IPK adalah 2.97 .

Hasil analisis OLAP untuk KPI lulusan berupa IPK dapat dilihat pada Gambar 5.

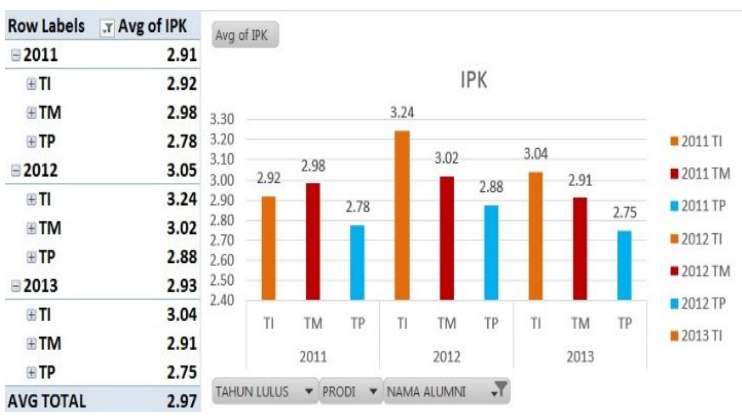

Gambar 5. Hasil analisis OLAP untuk KPI lulusan berupa IPK

\subsection{Analisis Metode Fuzzy Model Tsukamoto}

Proses analisis Metode Fuzzy model Tsukamoto ini mengolah data-data indeks KPI lulusan yang sudah dihasilkan dari analisis OLAP tersebut di atas menjadi sebuah informasi Performa KPI Lulusan dan tingkat Mutu Lulusan pada Perguruan Tinggi. Pengolahan data indeks KPI lulusan ini menggunakan proses FuzzyInference System (FIS) yang memiliki 3 (tiga) tahapan yaitu, fuzzifikasi, inferensi, dan defuzzifikasi.

Berdasarkan dari Dimensi Tahun dan Program Studi didapat beberapa hasil analisis metode Fuzzy model Tsukamoto ini bahwa proses inferensi terdapat $\alpha$-predikat (fire-strength) dari masing-masing dimensinya, antara lain dimensi Semua Angkatan dan Semua Program Studi. 


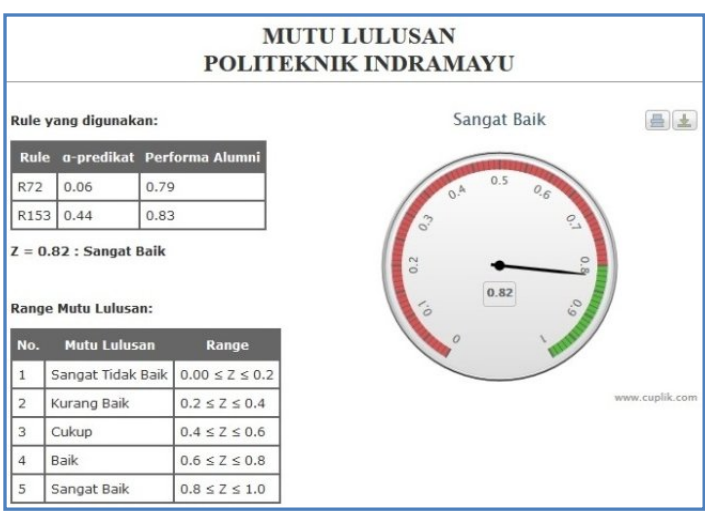

Gambar 6. Hasil Mutu Lulusan berdasarkan 3 Tahun (2011-2013) dan Semua Prodi (TI, TM, dan TP)

Hasil analisis metode Fuzzy model Tsukamoto ini bahwa proses inferensi terdapat $\alpha$-predikat (firestrength) yang bernilai dari 177 alumni keseluruhan selama 3 tahun terakhir (2011 s.d. 2013), dari 35 aturan yang digunakan, kemudian yang bernilai hanya 2 aturan (R72 dan R153), sehingga aturan tersebut lah yang memenuhi untuk dilakukannya proses perhitungan defuzzifikasi, rincian aturannya diberikan pada Tabel 2.

Tabel 2. Hasil Proses Inferensi Lulusan Politeknik Indramayu (Polindra) Selama 3 Tahun

Rule $\quad \alpha$-predikat $\quad$ Performa Alumni

$\begin{array}{ccc}\text { R72 } & 0.06 & 0.79 \\ \text { R153 } & 0.44 & 0.83\end{array}$

Proses pengkonversian setiap hasil dari inferensi sistem yang diekspresikan dalam bentuk fuzzyset ke satu bilangan real. Hasil konversi tersebut di implementasikan pada 2 aturan di atas untuk mendapatkan parameter tingkat Mutu Lulusan Politeknik Indramayu dalam 3 tahun (2011 s.d. 2013).

$$
\begin{aligned}
= & \frac{0.06 * 0.79+0.44 * 0.83}{0.06+0.44} \\
=\stackrel{.}{.} & =0.83
\end{aligned}
$$

\subsection{Analisis Performa KPI Lulusan dan Tingkat} Mutu Lulusan

Hasil analisis metode OLAP dan metode Fuzzy model Tsukamoto, dihasilkan bahwa apabila pada Performa KPI Lulusan dan tingkat Mutu Lulusan untuk ke lima indikator yang berdasarkan dimensi Pertiga Tahun dan Semua Program Studi.

Dalam dimensi pertiga tahun dan semua program studi ini didapat sebagai sampling data menggunakan lulusan 3 tahun (2011-2013) dan semua program studi (TI, TM, dan TP), pada Performa KPI Lulusan untuk rata-rata IPK adalah 2.97, rata-rata waktu tunggu adalah 4.9 bulan, rata-rata sertifikasi kompetensi adalah 56.25 poin, rata-rata kesesuaian bidang ilmu adalah $81.80 \%$, rata-rata kesesuaian stakeholder terhadap lulusan adalah $79.36 \%$.

Dari Performa Lulusan tersebut maka parameter Mutu Lulusannya adalah 0.83 yang termasuk dalam variabel linguistik "Sangat Baik". Hasil linguistik tersebut digunakan sebagai masukan untuk menentukan tingkat Mutu Lulusan, berdasarkan Tabel 2 (Chiew dan Salim, 2003). Terlihat bahwa nilai rata-rata Mutu Lulusan lebih besar sama dengan 0.8 dan lebih kecil sama dengan 1, maka Mutu Lulusannya "Sangat Baik". Hasil Performa Lulusan diberikan pada Gambar 7.

Hasil analisis metode Fuzzy model Tsukamoto pada sistem informasi lulusan dapat memberikan gambaran secara umum sebuah performa KPI lulusan dan tingkat mutu lulusan Perguruan Tinggi dalam pengambilan keputusan, metode Fuzzy model Tsukamoto juga membuktikan bahwa performa KPI lulusan dari analisis OLAP sistem informasi lulusan menjadi sebuah parameter tingkat keberhasilan dalam mengevaluasi lulusan.

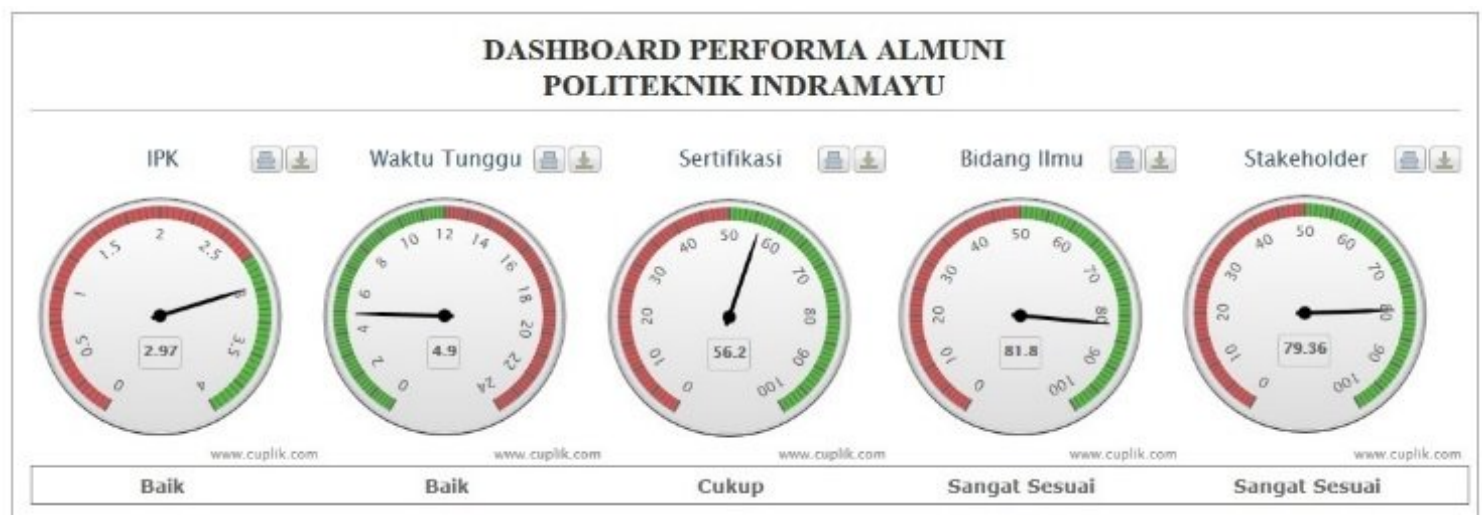

Gambar 7. Hasil performa lulusan berdasarkan 3 tahun (2011-2013) dan semua prodi (TI, TM, dan TP) 
Penelitian dengan analisis OLAP dan metode FuzzyLogic dengan pendekatan Fuzzy Inference System (FIS) model Tsukamoto dapat saling terintegrasi dalam membuat sebuah sistem informasi lulusan berbasis web sebagai bahan evaluasi terhadap performa lulusan dan mutu lulusan.

Keterkaitan metode OLAP dan metode Fuzzy model Tsukamoto ini bahwa keduanya dapat dipakai untuk mengevaluasi institusi pendidikan, pada hasil penelitian terdahulu metode OLAP hanya dipakai sebatas penyajian laporan dan metode Fuzzy Logic dipakai sebatas model Mamdani dan Takagi Sugeno untuk mengevaluasi institusi pendidikan, pada penelitian ini metode OLAP diterapkan sebagai pengukuran performa KPI lulusan dan Fuzzy Logic dalam pendekatan inferensi sistem model Tsukamoto diterapkan sebagai pengambilan keputusan dalam evaluasi mutu lulusan Perguruan Tinggi.

\section{Kesimpulan dan Saran}

Sistem informasi lulusan berbasis web portal yang data lulusannya dapat dianalisis menggunakan OLAP sehingga dapat memudahkan pihak manajemen institusi Perguruan Tinggi dalam mendukung keputusan terhadap parameter tingkat keberhasilan Mutu Lulusan Perguruan Tinggi dan dapat melihat perkembangan lulusan dalam bentuk tabel, grafik, dan dashboard.

Analisis OLAP menghasilkan berupa Performa KPI Lulusan berdasarkan dimensi tahun dan progam studi, sedangkan analisis metode Fuzzy model Tsukamoto dari studi kasus yang dilakukan pada Politeknik Indramayu dan ketiga program studi yaitu Teknik Informatika, Teknik Mesin, dan Teknik Pendingin dan Tata Udara, menghasilkan parameter tingkat Mutu Lulusan yang dapat digunakan dalam pengambilan keputusan untuk perbaikan Mutu Lulusan berikutnya pada Perguruan Tinggi.

Penelitian ini dapat dikembangkan dalam perancangan dan penerapan aplikasi OLAP yang dibangun masih belum terintegrasi secara langsung dengan database sistem informasi akademik, supaya dapat membantu manajemen institusi Perguruan Tinggi dalam menentukan parameter tingkat keberhasilan Mutu Lulusan, output dari proses OLAP perlu adanya penambahan dimensi selain dimensi tahun dan program studi, sehingga parameter tingkat keberhasilan alumni baik dari sisi Performa KPI maupun Mutu Lulusan bisa lebih baik lagi.

\section{Daftar Pustaka}

Chiew, T.K. and Salim, S.S., 2003. WEBUSE: Website Usability Evaluation Tool, Malaysian Journal of Computer Science, (16) 1, 47-57.
Cox, E., 1994. The Fuzzy Systems Handbook (A Prsctitioner's Guide to Building, Using, and Maintaining Fuzzy Systems), Massachusetts:Academic Press.Inc.

Golfarelli, M., Mandreoli, F., Penzo, W., Rizzi, S., dan Turricchia, E., 2012. OLAP query reformulation in peer-to-peer data warehousing, Information System 37, 393-411.

Hsu, K.C., and Li, M.Z., 2011. Techniques for finding similarity knowledge in OLAP reports, Expert Systems with Applications, 38, 3743-3756.

Ingoley, S.N., and Bakal, J.W., 2012. Evaluating Students Performance using Fuzzy Logic, International Conference, IJCA Proceedings on International Conference on Recent Trends in Information Technology and Computer Science, ICRTITCS (9): 15-20.

Jadac, J.J. and Panchal, M., 2012. Association Rule Mining Method On OLAP Cube, International Journal of Engineering Research and Applications, Vol. 2, Issue 2, 1147-1151.

Kimball, R. and Caserta, J., 2004. The Data Warehouse ETL Toolkit, Wiley Publishing, New York.

Kusumadewi, S., 2010. Aplikasi Logika Fuzzy untuk Pendukung Keputusan, Edisi 2, Graha Ilmu, Yogyakarta.

Laudon, C.K. and Jane, P., 2008. Essentials of Business Information Systems, 7th Edition, Pearson Prentice Hall.

Laudon, C.K. and Jane, P.L., 2010. Management Information System Managing The Digital Film Eleventh Edition, Pearson Education, Inc., Upper Saddle River, New Jersey.

Patria, B., 2013. Learning Environment and Graduates Transition Period, International Journal of Research Studies in Education, Vol. 2 (1), 25-40.

Pedersen, T.B., 2009. Multidimensional Modelling, Springer, Berlin/Heidelberg, 1777-1784.

Rouhani, S., Mehdi, G. and Mostafa, J., 2012. Evaluation model of business intelligence for enterprise system using fuzzy TOPSIS, Expert Systems with Applications 39, 3764-3771.

Turban, E., Aronson, J.E., and Liang, T.P., 2005. Sistem Pendukung Keputusan dan Sistem Cerdas, Terjemahan Dwi Prabantini, Andi Publisher, Yogyakarta.

Westerlund, P., 2008. Business Intelligence: Multidimensional Data Analysis, Master Thesis in Computing Science 30 ECTS Credits.

Yadav, R.S. and Singh, V.P., 2011. Modeling Academic Performance Evaluation Using Soft Computing Techniques: A Fuzzy Logic Approach, International Journal on Computer Science and Engineering IJCSE, Vol.3 (2), 381387. 